\title{
STREPTOCOCCUS EQUI SUBSP. ZOOEPIDEMICUS AS THE CAUSE OF MASS MORTALITY AMONG LABORATORY MICE
}

\author{
O. LITERAK and O. MRAZ \\ Department of Epizootiology and Microbiology, \\ University of Veterinary Science, 61242 Brno
}

Received December 27,1989

\begin{abstract}
Literák I., O. Mráz: Streptococcus equi subsp. zooepidemicus as the Cause of Mass Mortality among Laboratory Mice. Acta vet. Brno 60, 1991: 51-60

The report describes an epizootic caused by Streptococcus equi subsp. zooepidemicus among laboratory mice. The disease developed in a group of newly purchased 600 white mice of strain Swiss and spread also to the same mice of the laboratory flock. Death occurred in two waves (each lasting only a few days) during which $11.7 \%$ of the newly purchased mice and 40 (circa $4 \%$ ) mice of the original laboratory flock died.

The only clinical sign deserving mention was occasional oedema in the head region (inflammation of submandibular lymph nodes). Post-mortem examination revealed tumor lienis, larger or smaller in size, in all the cases. Cultivation from the internal parenchymas yielded streptococcal colonies in growth phases $M$ and $D$. This dissociation was reversible; it was present up to the 25 th passage on blood agar after which phase $\mathbf{D}$ gradually disappeared.

The epizootic was liquidated by two courses of five day's experimental treatment, apart, with a penicillin-streptomycin mixture added to the drinking water.
\end{abstract}

Strepcoccus equi subsp. zooepidemicus, diseases of laboratory animals, white mouse

Streptococcus equi subsp. zooepidemicus has been isolated, under its earlier name of Streptococcus zooepidemicus, from horses, sheep, pigs, domestic fowls, minks and occasionally also from guinea-pigs suffering from various affections. (Hahn 1980). To our knowledge, only one paper has reported its incidence in white mice (Pop et al. 1964) and therefore we cite here these published observations in detail:

The epizootic occurred in a large flock of laboratory animals comprising, among other animals 16000 breeding mice in separate groups of 1000 mice. Its development was associated with November cold and with a 16-h failure of air-conditioning during which the temperature in the rooms ranged between 14 and $25{ }^{\circ} \mathrm{C}$ and the relative air humidity declined by $28 \%$. Another factor involved was the large number of pregnant and nursing mice because only these adult animals developed the disease and died.

The primary source of the infection was not mentioned in the paper but bacteriological examination of clinically healthy mice revealed an average of $14 \%$ carriers in the rooms. The streptococci were members of group C, were pathogenic and were found in the pharynx in more than a half of the positive cases.

The first deaths were recorded the 4 th day after the climatic shock. Within a week the death rate increased from the original 0.2 to $0.4 \%$ to 3.4 to $8.9 \%$ daily, depending on the mouse strains. At the beginning of the epizootic the septicaemic form with somnolence, severe dyspnoea and, occasionally, diarrhoea prevailed in almost of the affected animals. It lasted 1 to 3 days and its outcome was fatal. The other symptoms were maxillary adenopathy with fistulas and deformities of this region as well as further suppurative processes on the limbs observed mainly in those strains of mice where fatal cases were sporadic.

At the end of the epizotic two further, hitherto unknown, forms of the disease were observed: benign streptodermitis on the tail skin and streptococcal pseudoectromelia also on the tail. This was manifested by one or several brown-and black crusts whose suppurative underlying strata 
extended as far as the vertebrae. This condition resulted either in fatal septicaemia or loss of the distal portion of the tail within one to two weeks.

The pathological changes varied with the duration of the disease. In the septicaemic form they included hyperaemia of all org ns and maked splenic tumours. In the protracted cases they included polyadenopathy, miliary abscesses in the internal organs, enlargement and decolorization of the liver, haemorrhagic duodeno-jejunal enteritis and tumor lienis. Splenomegaly proved pathognomic in all forms of the disease including infarct zones which butted upright onto the margin and ran across the organ.

Isolation attempts from the mice that died during the epizootic yielded exclusively beta-haemolytic streptococci of group $\mathrm{C}$, namely $S$. zooepidemicus in growth phase $M$. When administered intranasally or intraperitoneally, they produced an acute form of the disease within 1 to 4 days; the $\mathrm{LD}_{50}$ was 3 to $4.10^{2}$ microbial cells $\cdot \mathrm{ml}^{-1}$.

Since attempts to control the epizootic with routine sanitary measures proved inefficient, feed medication with a mixture of sulphadiazine and dicillin (a kind of penicillin) was started from the 8th day of the outbreak. This brought about a marked improvement: as soon as 3 days after the feed medication was started the mortality in the most affected strain of mice fell from $8.9 \%$ to only $0.3 \%$.

\section{Case report}

At the beginning of July 1984 a total of 600 outbred white mice of strain Swiss were purchased from a specialized breeding flock of laboratory mice in $\mathrm{D}$. V. They were placed in 12 wooden boxes and added to our flock. All the animals were fed ST1 VELAZ, a commercial granulated feed mixture, and received tap water. The first solitary deaths occurred in the 1st week and could be accounted for by stress in consequence of long transport in a van. The symptoms included considerable apathy, bristled hair and also diarrhoea reminiscent of salmonellosis.

A mass mortality among the newly-purchased animals occurred 14 days later when 40 (40\%) mice in two boxes $(6.66 \%$ out of the total number of 600 mice) died within a few days, this time without any particular clinical signs. The two boxes including the 60 surviving mice were liquidated and the whole room housing also the same white mice of our flock and laboratory sewer-rats was disinfected by treating the floor with odorit, and the walls and equipment with $2 \%$ solution of chloramine BS. The mice in the remaining 10 boxes were given a mixture of penicillin and streptomycin in the drinking water for 5 days.

A new flare-up of the infection occurred 2 weeks after the disinfection. At this time $30(60 \%)$ out of 50 mice in one box (6\% out of the total number of circa 500 animals) died within a few days. In the remaining boxes and among the mice of our original flock we either recorded only subacute to chronic cases with signs of apathy and somnolence or the mice died only after their submandibular lymph nodes became swollen and incipient paresis of the hind limbs was observed.

At this stage of infection the antibiotic treatment was started in mice of our original flock and repeated in the newly-purchased animals. Afterwards no further deaths occurred and the room was disinfected once again.

\section{Materials and Methods}

Five strains of beta haemolytic streptococci isolated from the mice that died at the beginning and during the first flare-up of the infection were subjected to a thorough examination.

In view of the dissociation of the cultures into mucous and minute colonies, the latter of which were reminiscent of growth phase $\mathrm{L}$, the examination was extended to include the technique of agar fixation according to Klieneberger (1934).

Species identification was based on the determination of group antigen which was obtained by acid extraction as modified by Lancefield (1933). Precipitation using the corresponding antisera (Institute of Sera and Vaccines, Prague) was carried out in agar gel according to Ouchterlony (1949).

The choice of growth and biochemical features was guided by recent differentiation tables (Hahn 1980 ) and their determination was based mainly on standard bacteriological methods (Cowan and Steel 1974).

For later bioassays on a new generation of mice of our own flock we used fairly stabilized M-phases of the strains grown in meat-peptone broth. Ten pairs of mice were each inoculated with $0.2 \mathrm{ml}$ of 1:10 i.p. and separately with $0.2 \mathrm{ml}$ of $1: 10 \mathrm{~s}$. c. into the groin. Moreover, 2 rabbits and two guinea-pigs were inoculated i. p. with strain No. 1 using $1 \mathrm{ml}$ and $0.5 \mathrm{ml}$ of undiluted culture, respectively. 


\section{Results}

Post-mortem section revealed enlargement and stiffness of the spleen, occasional hyperaemia of the kidney and, in subacute and chronic cases, also enlargement of the submandibular lymph nodes (Fig. 1 and 2).

Culture on blood agar with sheep blood yielded beta haemolytic streptococci from all internal parenchymas. Their smooth colonies were of two types (Fig. 3). One type consisted of colonies having 1.5 to $2 \mathrm{~mm}$ in diameter and showing a moderately elevated profile. The other type included colonies that were only 0.1 to $0.2 \mathrm{~mm}$ in diameter, were convex and grew into the nutrient medium. Their morphology is shown in Fig. 4. No frankly gram-negative or giant cells with vacuolization were observed (Fig. 5 and 6 ).

The two types of colonies dissociated from one another up to the 25th passage after which the subtle phase gradually disappeared and only growth phase $M$ remained. Its relatively large colonies and their considerable tendency to coalesce are accounted for by a hyaluronic acid capsule. The evidence of it is the outcome of the decapsulation test (Fig. 7), particularly the more delicate growth at the rim of the central well containing hyaluronidase.

The results of double diffusion in agar gel are shown in Fig. 8. The marked precipitate and both the positive and negative controls provide evidence for group antigen $\mathrm{C}$.

Fig. 1. Deformity of a mouse head in consequence of enlargement (inflammation) of the submandibular lymph nodes. 


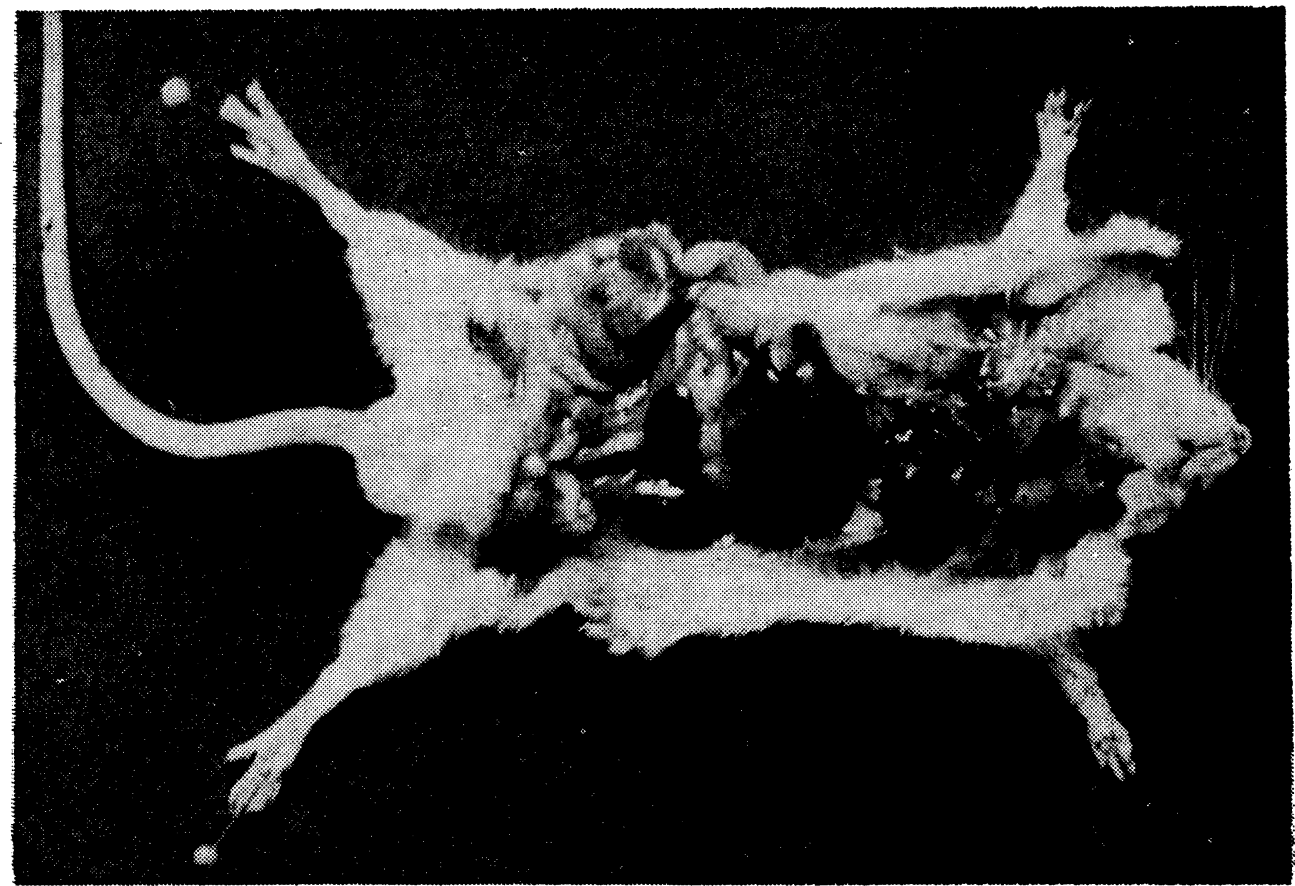

Fig. 2. Post-mortem finding in the mouse of Fig. 1 showing the enlarged submandibular lymph nodes and tumor lienis.

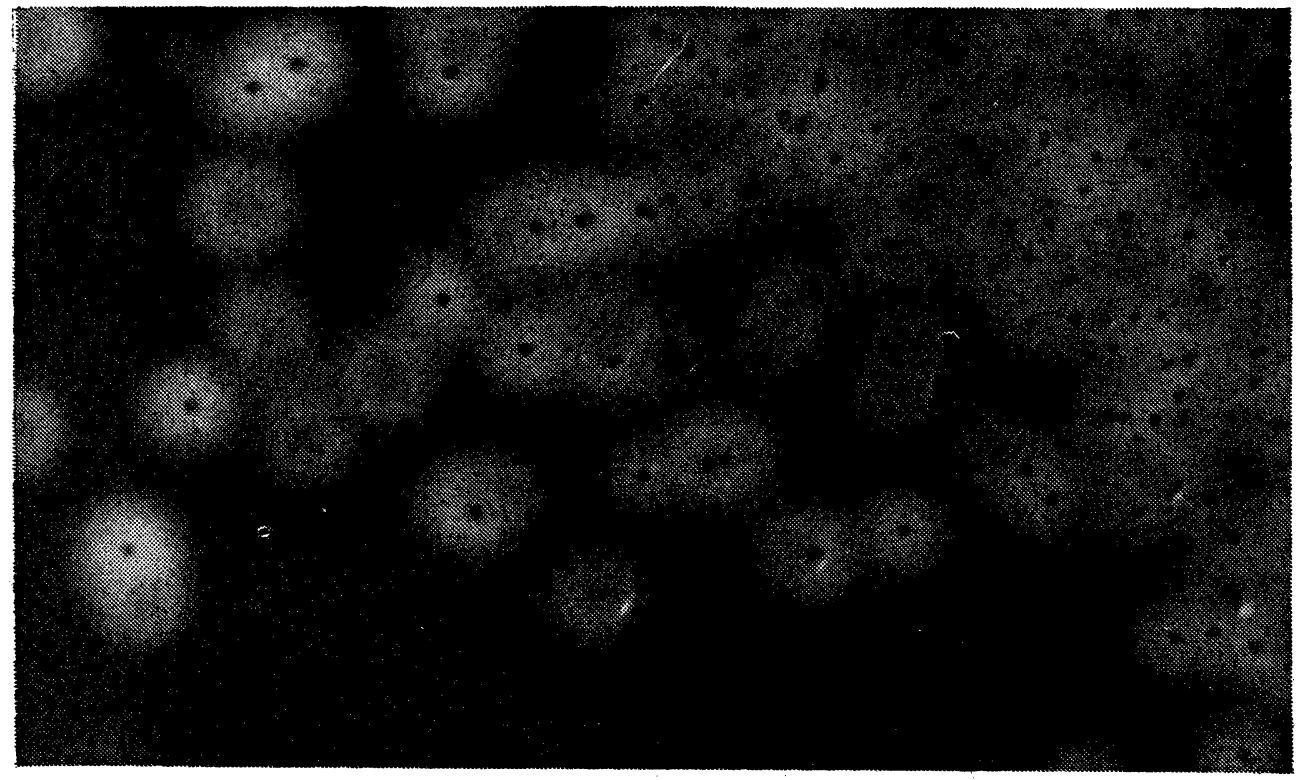

Fig. 3. Dissociation of the colonies of J.e equ subsp. zooepicuemicus strain 1 into growth phases $M$ (large colonies) and D (dot-like colonies); 48-h culture on blood agar; magnification $1: 3$. 


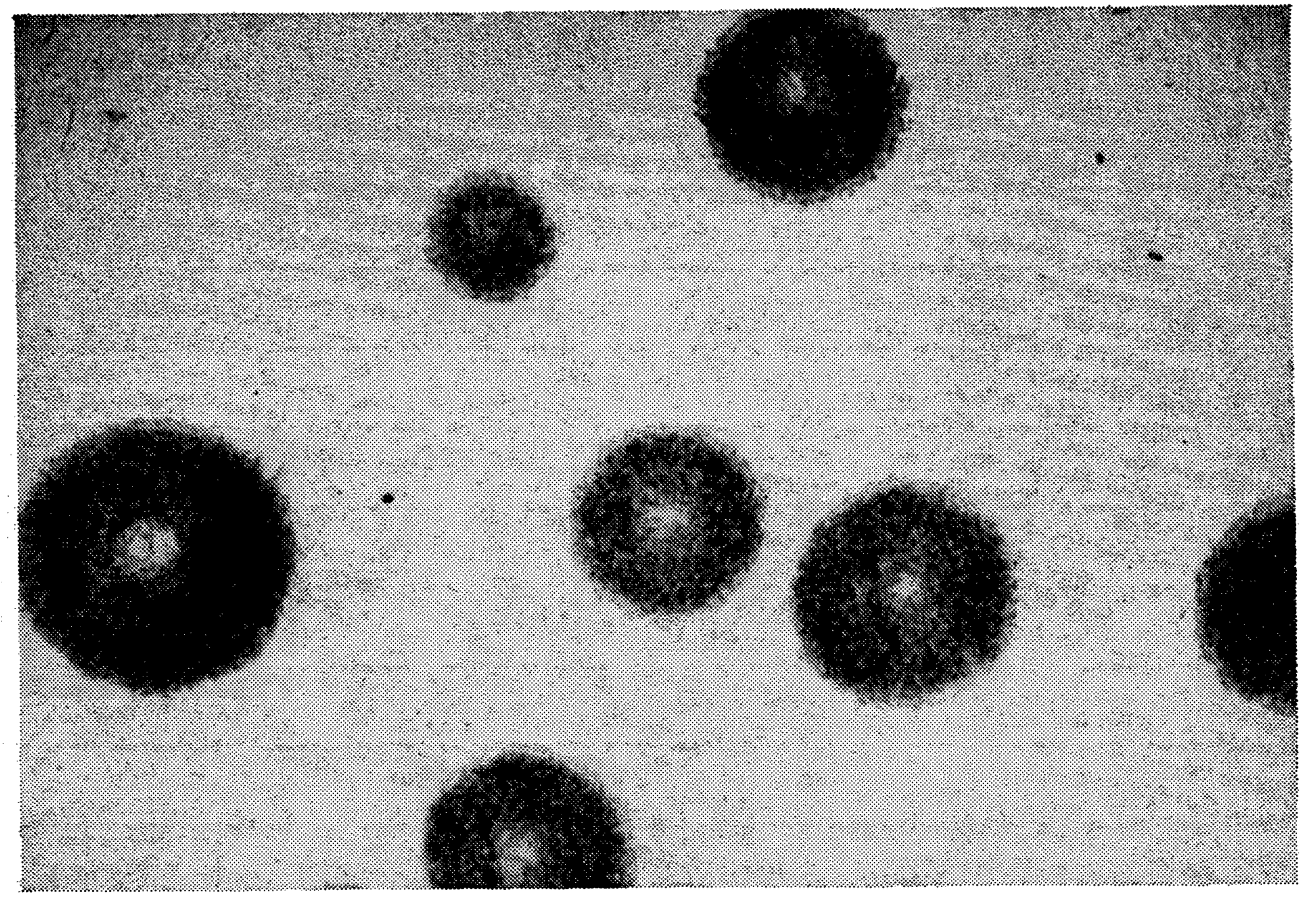

Fig. 4. Morphology of $S$. equi subsp. zooepidemicus colonies in the growth phase $D$ after agar fixation; 36-h culture from serum agar; magnification $1: 60$.

All five strains were facultatively anaerobic and besides growing on blood agar grew also in meat-peptone broth. The stabilized $M$-phase formed there large sedimentation floccules, whereas the almost pure subtle phase looked like diffuse turbidity. No growth was observed at 10 and $45^{\circ} \mathrm{C}$, at $6.5 \% \mathrm{NaCl}$ concentration, at $\mathrm{pH} 9.6$ and under addition of $40 \%$ bile. Also cultivation attempts on Endo and McConkey agar yielded negative results.

Biochemical activity of the strains was found mainly in saccharides; acidification was shown by glucose (without gas formation), fructose, galactose, maltose, lactose, saccharose, starch, sorbitol, esculin and, with delay, also by salicin. As to the remaining substrates, the only result deserving mention was the positive outcome of examination for arginine-dihydrolase.

Other tests yielded negative results. This applies both to the remaining saccharides (arabinose, rhamnose, trehalose, raffinose, inulin, dulcitol, glycerol, mannitol and inositol) and to gelatine, skim milk, casein, human plasma, ornithine, lysine, urea and hippurate. Negative results were also obtained in tests for catalase, oxidase, nitrate reduction, for acetoin, hydrogen sulphide and indole production and for solubility in bile.

In view of all the morphological, tinctorial, growth, biochemical and antigenic properties of the strains we concluded that the species was Streptococcus equi subsp. zooepidemicus which was present in the reversible growth phases $M$ and $D$.

At the beginning of the epizootic we also tested, for practical reasons, the sensitivity of the strains to common antibiotics with the plate method using LACHE- 


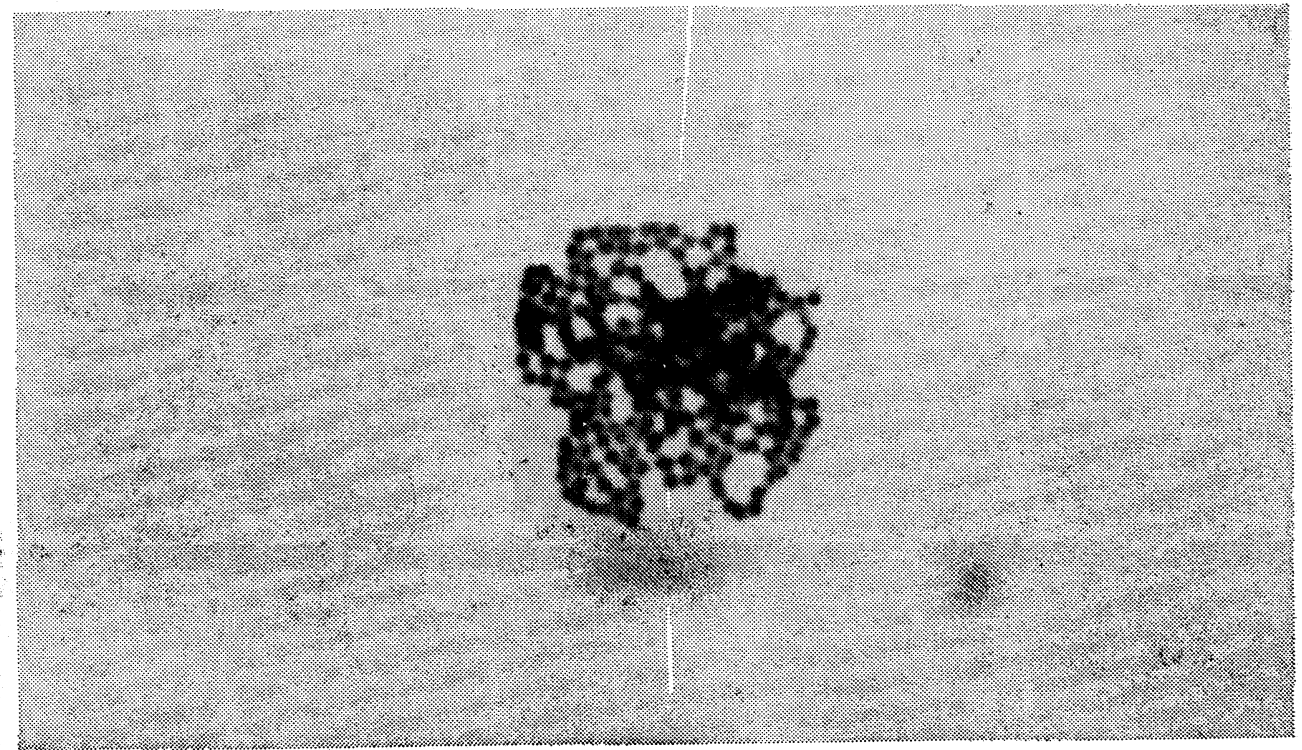

Fig. 5. Same as in Fig. 4: 4-h colony from serum agar; Giemsa; magnification $1: 1000$.

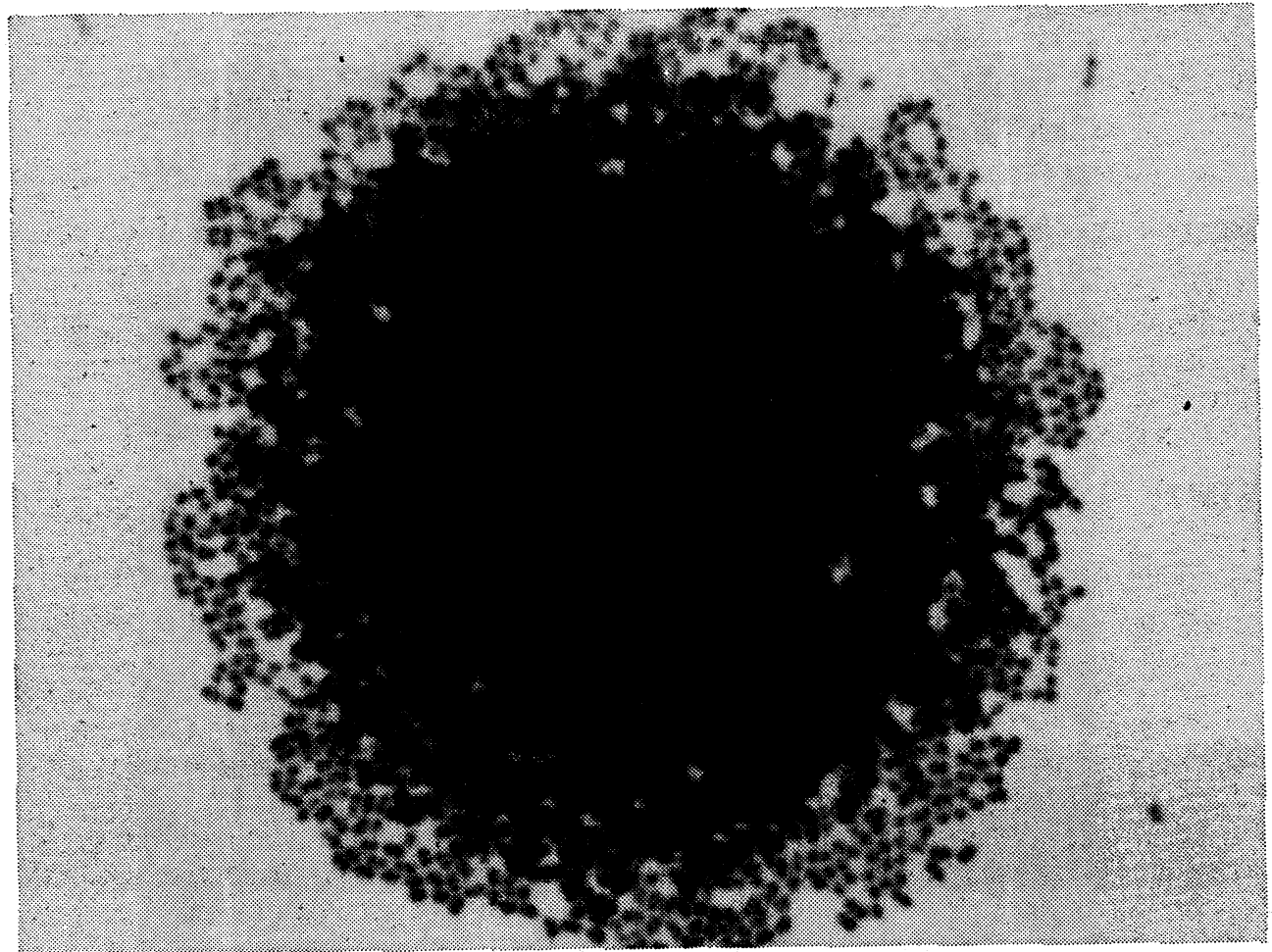

Fig. 6. Same as in Fig. 4; 12-h colony from serum agar; Giemsa; magnification $1: 1000$. 


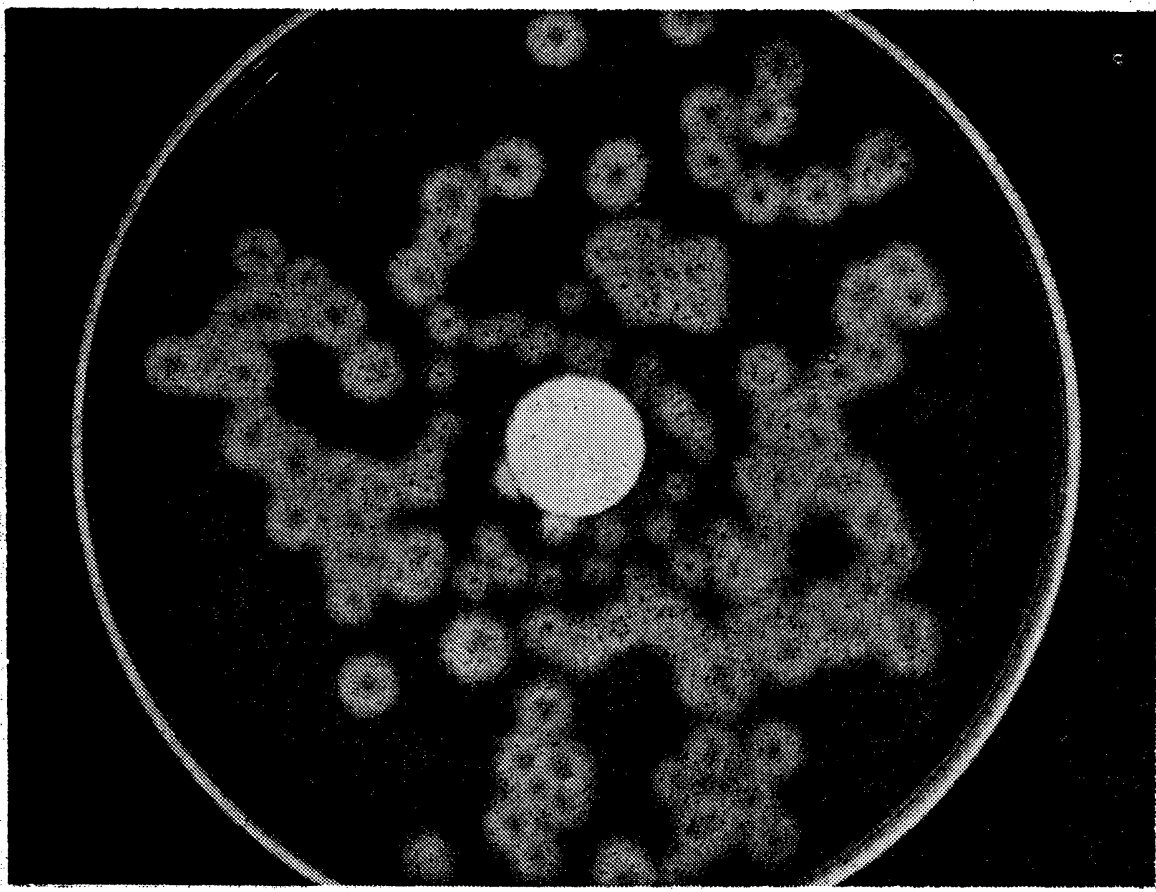

Fig. 7. Positive result of the decapsulation test with $M$-phase of S. equi subsp. zooepidemicus No 1; 24-h culture on blood agar; hyaluronidase SEVAC in the central well; magnification $1: 1$.

MA test discs. In these tests chloramphenicol, oxytetracycline and streptomycin proved most efficient, whereas penicillin was at the borderline of clinical usefulness and neomycin showed no growth inhibition zone at all.

With penicillin we used, in addition, the dilution method in nutrient broth. The results obtained for the two phases were practically the same: minimum bacteriostatic concentration (MIC) was 0.1 I.U... ml-1 and minimum bacteriocidal concentration did not exceed 10 I.U. penicillin . $\mathrm{ml}^{-1}$.

The clinical signs observed in the inoculated mice included, besides usual somnolence and hair bristling, also oedema and turning blue of the adjacent hind limb in one case (strain No. 1, s.c.). Hundred per cent mortality occurred in all ten groups either on the 2nd day (i.p.) or during the 2 nd to the 3 rd day (s.c.). The only conspicuous findings on subsequent post-mortem examination were moderate tumour of the spleen and occasionally hyperaemia of the kidney. Cultivation from all internal parenchymas yielded invariably the original streptococcal strains. Rabbits and guinea-pigs survived administration of the afore-mentioned doses of fully virulent strain No. 1 without damage.

The $\mathrm{LD}_{50}$ of strain No. 1 is shown in Table 1 . The observation period was 2 weeks but in most cases death occurred the 3rd to the 5th day. From the computation according to Reed and Muench (1938) it appears that the $\mathrm{LD}_{50}$ was $0.2 \mathrm{ml}$ of 24 -h broth culture diluted $1: 131072$, which at its density of 206.438 . $.10^{6}$ represents $3.15 .10^{2}$ bacterial cells. 


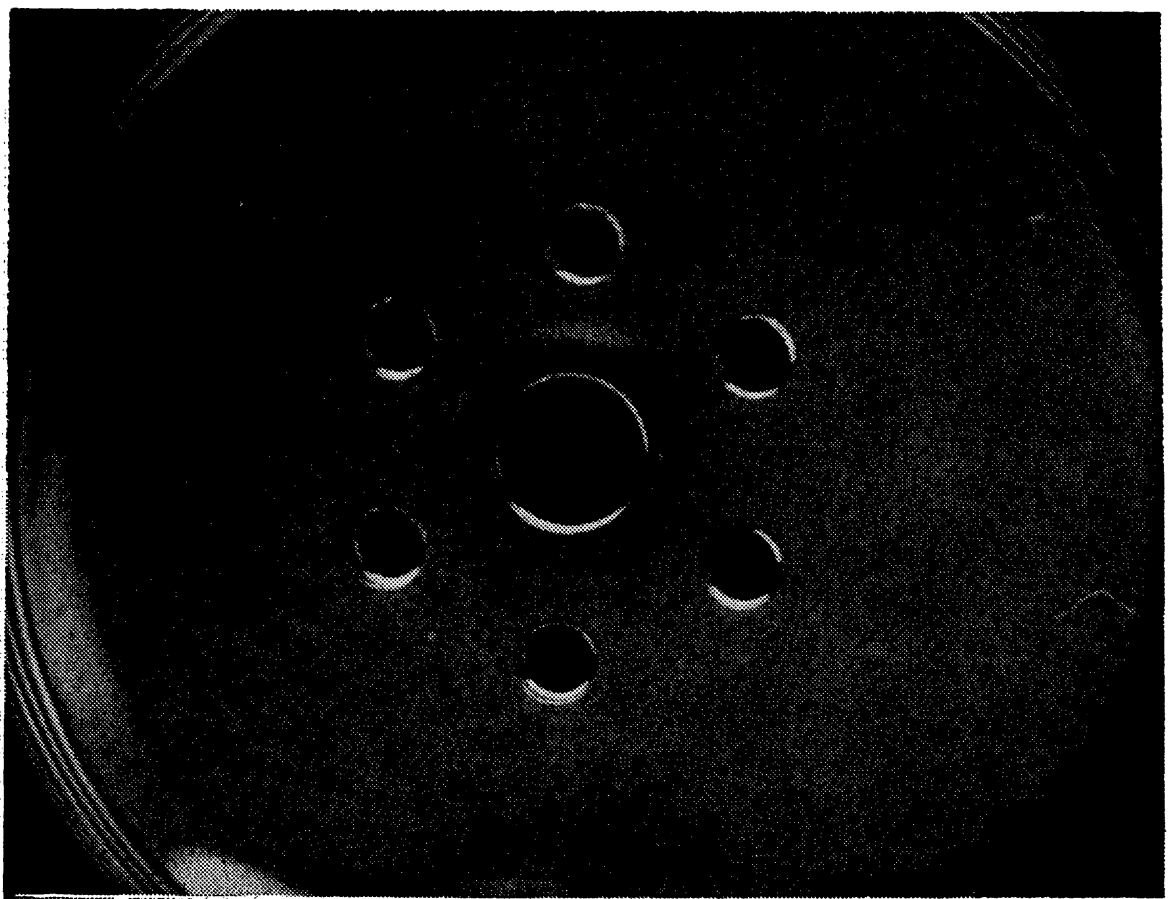

Fig. 8. Example of the precipitation reaction using streptococcal antiserum of group $C$ (in the central well). Antigens (extracts) from the strains are in the peripheral wells in the order indicated by the arrow: $S$. equi subsp. zooepidemicus No. 1, Streptococcus equisimilis No.41/59 and Streptococcus agalactiae No. 6/50. Exposure for $48 \mathrm{~h}$ at laboratory temperature.

Table 1

$L_{50}$ of Streptococcus equi subsp. zooepidemicus No. 1 for white mouse

\begin{tabular}{|c|c|c|c|c|c|c|c|}
\hline Dilution & Dead/Whole & Dead & Alive & Dead & Alive & Dead/Whole & $\%$ of dying \\
\hline $\begin{array}{r}1: 4096 \\
16384 \\
65536 \\
262144 \\
1048576 \\
4194304\end{array}$ & $\begin{array}{l}4 / 4 \\
3 / 4 \\
3 / 4 \\
1 / 4 \\
1 / 4 \\
0 / 4\end{array}$ & $\begin{array}{l}4 \\
3 \\
3 \\
1 \\
1 \\
0\end{array}$ & $\begin{array}{l}0 \\
1 \\
1 \\
3 \\
3 \\
4\end{array}$ & $\begin{array}{r}12 \\
8 \\
5 \\
2 \\
1 \\
0\end{array}$ & $\begin{array}{r}0 \\
1 \\
2 \\
5 \\
8 \\
12\end{array}$ & $\begin{array}{l}12 / 12 \\
8 / 9 \\
5 / 7 \\
2 / 7 \\
1 / 9 \\
0 / 12\end{array}$ & $\begin{array}{c}100 \\
88.9 \\
71.4 \\
28.6 \\
11.1 \\
0\end{array}$ \\
\hline $\begin{array}{r}\operatorname{LD}_{s 0}^{x} \\
\text { Density of culture } \\
\mathrm{LD}_{\mathrm{so}}\end{array}$ & $\begin{array}{l}0.5 \\
65536 \cdot 4^{0,5} \\
65536 \cdot 2 \\
0.2 \mathrm{ml} \text { od cultu } \\
206.438 \cdot 10^{8} \mathrm{~b} \\
3.15 \cdot 10^{2} \text { bacte }\end{array}$ & $\begin{array}{l}\text { re dilu } \\
\text { icterial } \\
\text { rial cel }\end{array}$ & $\begin{array}{l}131072 \\
\mathrm{ml}^{-1}\end{array}$ & & & & \\
\hline
\end{tabular}

\section{Discussion}

Streptococcal epizootics in booth wild and laboratory mice are rather rare. Moreover, the species of the causative agent in the earliest studies (Kutschera 1908) remained more or less undisclosed because in these reports numerous of 
our current biochemical tests and, up to the early thirties (Loewenthal 1931), also serological determination of group antigen were lacking. Furthermore, in some cases the clinical picture or post-mortem findings may have been obscured by mixed infection with staphylococci (Kutschera 1908) or francisellae (Bell et al. 1958). Of more comparative value in this respect are infections produced by group A streptococci alone as described, a.o., by Hook et al. (1960). These writers reported mainly enlargement of the submandibular lymph nodes with formation of abscesses, bacteriaemia, pneumonia and, occasionally, also meningitis.

The epizootic among mice of strain Swiss described in the present report resulted from our purchase of indubitable carriers. Additional factors involved may have been relatively long transport in a van and slow adaptation of the animals to new conditions. The course of the epizootic and the clinical and pathological findings are comparable with the data reported in the basic study of Pop et al. (1964) even though we did not observe infarcts in the spleen and streptococcal affections on the tail. On the other hand, it became apparent that occasional inflammation of the submandibular lymph nodes can occur also in epizootics produced by streptococci of group A (Hook et al. 1960).

The repeated flare-up of the infection (after experimental treatment with antibiotics) is, in our view, a confirmation that this therapy may not result in the disappearance of the carrier strains from the body of the host (Pop et al. 1964). Other eradication attempts (such as antigen shock) were not made in our study. An observation of some interest may also be the finding of temporary reversible dissociation of the microbial strains into growth phases $M$ and D the morphology of which we also documented by inclusion of the relevant photographs.

\section{Streptococcus equi subsp. zooepidemicus jako př́čina hromadného hynutí laboratorních myši}

V práci je popsána epizootie Streptococcus equi subsp. zooepidemicus u laboratorních myší. Onemocnění vzniklo ve skupině 600 přikoupených myší kmene Swiss a rozšírilo se i na stejné myši vlastního chovu. Dvojí vlna hynutí trvala vždy jen několik dní a postihla $11,7 \%$ přikoupených, resp. i 40 (cca $4 \%$ ) ostatních myší.

Z chorobných změn zaslouží zmínku jen ojedinělé otoky $\mathrm{v}$ krajině hlavy (zánět podčelistních mízních uzlin) a po smrti ve všech případech také větší či menší tumor lienis. Kultivace $\mathrm{z}$ vnitrrních parenchymů poskytla streptokokové kolonie $\mathrm{v}$ růstových fázích $\mathrm{M}$ a $\mathrm{D}$. Tato disociace byla reverzibilního charakteru a přetrvávala až do 25. pasáže na krevním agaru, kdy D-fáze postupně vymizela.

Epizootii se podařilo zlikvidovat experimentální léčbou za použití směsi penicilinu se streptomycinem $\mathrm{v}$ napájecí vodě, a to dvojí pětidenní kúrou s intervalem 14 dnů.

\section{Streptococcus equi subsp. zooepidemicus в качестве причины массовой гибели лабораторных мышей}

Эпизоотия возникла в группе 600 дополнительно купленных мышей штамма Swiss, и охватила также мышей собственного содержания. Две волны замора длились всегда несколько дней и коснулись $11,7 \%$ күпленных, а также 40 штук (около $4 \%$ ) остальных мышей. 
Из болезненных изменений следует отметить отдельные отечности в области головы (воспаление подчелюстных лимфатических узлов) и после смерти во всех случаях также в большей или меньшей степени түмор селезенки. Культивированием из внутренних паренхимов получили колонии стрептококков в фазах роста M и D Данная диссоциация отличалась обратимым характером и длилась до 25 пассажа кровяного агара, когда фаза D постепенно исчезла.

Эпизоотию удалось пиквидировать применением смеси пенициллина и стрептомицина в питьевой воде, а именно двойном пятидневном лечением с промежутком две недели.

\section{References}

BELL, J. F.-OWEN, C. R.-JELLISON, W. L.: Group A Streptococcus infections in wild rodents. J. Inf. Dis., 103, 1958: 196-203

COWAN, S. T. - STEEL, K. J.: Cowan and Steel's Manual for Identification of Medical Bacteria. 2. edit. Cambridge Univ. Press, London 1974, 238 p.

HAHN, G.: Streptokokken. In: BLOBEL, H., SCHLIESSER, T. (red.): Handbuch der bakteriellen Infektionen bei Tieren. VEB Gustav Fischer, Jena 1980. Bd II, 756 p.

HOOK, E. W.-WAGNER, R. R.-LANCEFIELD, R. C.: An epizootic in Swiss mice caused by a group A streptococcus, newly designated type 50. Am. J. Hyg., 72, 1960: 111-119

KLIENEBERGER, E.: The colonial development of the organism of pleuropneumonia and agalactia on serum agar and variations of the morphology under different condition of growth. J. Path. Bact., 39, 1934: 409-420

KUTSCHERA, F.: Eine spontane Streptokokkenepidemie unter weissen Mäusen. Zbl. Bakt. I. Abt. Orig., 46, 1908: 671-672

LANCEFIELD, R. C.: A serological differentiation of human and other groups of hemolytic streptococci. J. exp. Med. 57, 1933: 571

LOEWENTHAL, H.: Ein Streptokokkenstamm von ungewöhnlicher Pathogenität. Ztschr. Hyg. Inf.-krkh., 113, 1931: 445-456

OUCHTERLONY, O.: Antigen-antibody reactions in gels. Acta Path. Microbiol. Scand., 26, 1949: 507-515

POP, A.-BALDOVIN-AGAPI, C.-OPRISAN, A.-POTORAC, E.-OPRISAN, R.-MIHALCO, F.: Épizootie proroquée par des streptocoques de groupe C - Str. zooepidemicus chez les souris de laboratoire. Arch. Roum. Path. exp. Microbiol., 23, 1964: 123-132

REED, L. F. - MUENCH, H.: A simple method of estimating 50 per cent endpoints. Am. J. Hyg., 27, 1938: 493-497 